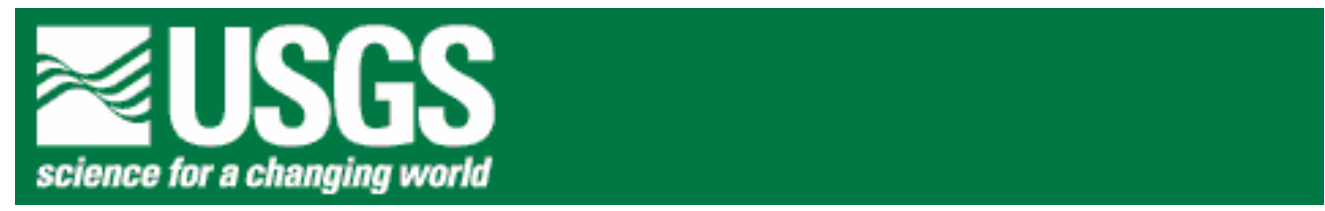

\title{
Determination of Total Mercury in Biological and Geological Samples
}

\section{A presentation for the 2004 Teledyne Leeman Labs "Seminar on Low-Level Mercury Data and Analyses"}

By James G. Crock

U. S. Geological Survey, M.S. 964, Federal Center, Denver, CO 80225

Open-File Report 2005-1030

2005

This report has not been reviewed for stratigraphic nomenclature.

U.S. DEPARTMENT OF THE INTERIOR

U.S. GEOLOGICAL SURVEY 


\section{U.S. DEPARTMENT OF THE INTERIOR \\ Gale Norton, Secretary \\ U.S. GEOLOGICAL SURVEY \\ Charles G. Groat, Director}

For additional information

write to:

Team Chief Scientist

Crustal Imaging and Characterization Team

U.S. Geological Survey

Box 25046, Mail Stop 964

Denver, CO 80225-0046
Copies of this report can

be purchased from:

Books and Open-File Reports

U.S. Geological Survey

Denver Federal Center

Box 25046

Denver, CO 80225-0046 


\section{TABLE OF CONTENTS}

Abstract

Selected References

Slides from the Presentation
Page

4

6

7

Page 3 


\title{
Determination of Total Mercury in Biological and Geological Samples
}

\section{A presentation for the 2004 Teledyne Leeman Labs: "Seminar on Low-Level Mercury Data and Analyses" **}

\author{
James. G. Crock
}

\begin{abstract}
${ }^{* *}$ This invited presentation was given by the author on September 23, 2004, in Boulder, Colorado, at a seminar/workshop on low-level mercury that was sponsored by Teledyne Leeman Laboratories, Hudson, NH 03051 (603-886-8400; www.LeemanLabs.com).
\end{abstract}

\section{ABSTRACT}

The analytical chemist is faced with several challenges when determining mercury in biological and geological materials. These challenges include widespread mercury contamination, both in the laboratory and the environment, possible losses of mercury during sample preparation and digestion, the wide range of mercury values commonly observed, ranging from the low nanogram per gram or per liter for background areas to hundreds of milligrams per kilogram in contaminated or orebearing areas, great matrix diversity, and sample heterogeneity ${ }^{1}$. These factors can be naturally occurring or anthropogenic, but must be addressed to provide a precise and accurate analysis.

Although there are many instrumental methods available for the successful determination of mercury, no one technique will address all problems or all samples all of the time. The approach for the determination of mercury used at the U.S. Geological Survey, Crustal Imaging and Characterization Team, Denver Laboratories, utilizes a suite of complementary instrumental methods when approaching a study requiring mercury analyses. Typically, a study could require the analysis of waters, leachates or selective digestions of solids, vegetation, and biological materials such as tissue, bone, or shell, soils, rocks, sediments, coals, sludges, and(or) ashes. No one digestion or sample preparation method will be suitable for all of these matrices. The digestions typically employed at our laboratories include: (i) a closed-vessel microwave method using nitric acid and hydrogen peroxide, followed by digestion/dilution with a nitric acid/sodium dichromate solution, (ii) a robotic open test-tube digestion with nitric acid 
and sodium dichromate, (iii) a sealed Teflon® vessel with nitric acid and sodium dichromate, (iv) a sealed glass bottle with nitric acid and sodium dichromate, or (v) open test tube digestion with nitric and sulfuric acids and vanadium pentoxide. The common factor in all these digestions is that they are very oxidative to ensure the conversion of all mercury forms into $\mathrm{Hg}$ (II). Each method of digestion has its advantages and limitations.

The method of detection used in our laboratories involves a combination of an inhouse, custom, classic continuous-flow cold-vapor atomic absorption spectrometry (CVAAS), a commercially available, automated, flow-injection and a continuous flow coldvapor atomic fluorescence spectrometry (CV-AFS) systems, and a relatively new, automated and integrated approach where solid or liquid samples are thermally decomposed under an oxygen atmosphere (a nitrogen atmosphere is used for coals) and the released mercury vapor trapped onto a gold gauze and then thermally released into an AAS system. Other less frequently used instrumental methods available for the determination of mercury include inductively coupled plasma - optical emission spectrometry (ICP-OES), inductively couple plasma - mass spectrometry (ICP-MS) (both solution nebulization and laser ablation), and instrumental neutron activation analysis (INAA).

Results from two case studies involving the determination of mercury in the challenging matrices of biological materials will be presented. These will include fillet, liver and stomach-content samples from grayling for a baseline/background study in Alaska, and samples of meat tissue and shell material from Tanner crabs from Glacier Bay, Alaska. These studies show that the method of digestion is more important than a very sensitive detection limit for mercury. 


\section{Selected References}

Crock, J.G., 1996, Mercury: Chapter 29, in, Methods of soil analysis, Part 3: Chemical methods, D.L. Sparks, Editor, Number 5 in the Soil Science Society of America Book Series, Soil Science Society of America, Inc., Madison, WI, pp. 769-791.

Crock, J.G., Arbogast, B.F., and Lamothe, P.J., 1999, "Laboratory methods for the analysis of environmental samples," in G. S. Plumlee and M.J. Logsdon (Eds.), The environmental geochemistry of mineral deposits, Part A. Processes, techniques, and health issues: Society of Economic Geologists, Reviews in Economic Geology. 6A: 265-287.

Gough, L.P., Crock, J.G., Seal, R.R., Wang, Bronwen, and Weber-Scannell, Phyllis, 2004, Biogeochemistry, stable-isotopic composition, and feeding habits of arctic grayling (Thymallus arcticus) in the Lower Fortymile River, Eastern Alaska, in Selected geochemical and biogeochemical studies of the Fortymile River Watershed, Alaska, L.G. Gough (ed.) U.S. Geological Survey Professional Paper 1685, pp. 20-43.

Porcella, D.B., Huckabee, J.W., and Wheatley, Brian (Eds.), 1995, Mercury as a global pollutant-Proceedings of the Third International Conference held in Whistler, British Columbia, July 10-14, 1994, Water, Air, and Soil Pollution, 80, 1-4, $1336 \mathrm{p}$.

Sigel, Astrid, and Sigel, Helmut (Eds.), 1997, Mercury and its effects on environment and biology, v. 34, Metal ions in biological systems, Marcel Dekker, Inc., New York, $604 \mathrm{p}$.

Taggart, J.E., Jr. (Ed.), 2002, Analytical methods for chemical analysis of geological and other materials, U.S. Geological Survey: U.S. Geological Survey Open-File Report 02-223 (available online at: http://pubs.usgs.gov/of/2002/ofr-02-0223/

Watras, C.J., and Huckabee, J.W. (Eds.), 1994, Mercury pollution-Integration and synthesis: Lewis Publishers, Boca Raton, Fla., 727 p. 


\section{Determination of Total Mercury in Biological and Geological Samples James G. Crock}

\section{United States Geological Survey}

Crustal Imaging and Characterization Team, Geologic Discipline M.S. 964, DFC, Lakewood, CO 80225 jcrock@usgs.gov

$$
\text { 303-236-2462 }
$$




\section{CICT, GD, USGS}

- Analytical Chemistry and Geochemistry - methods development and application

- Geophysics, methods development, and applications

- http://crustal.usgs.gov

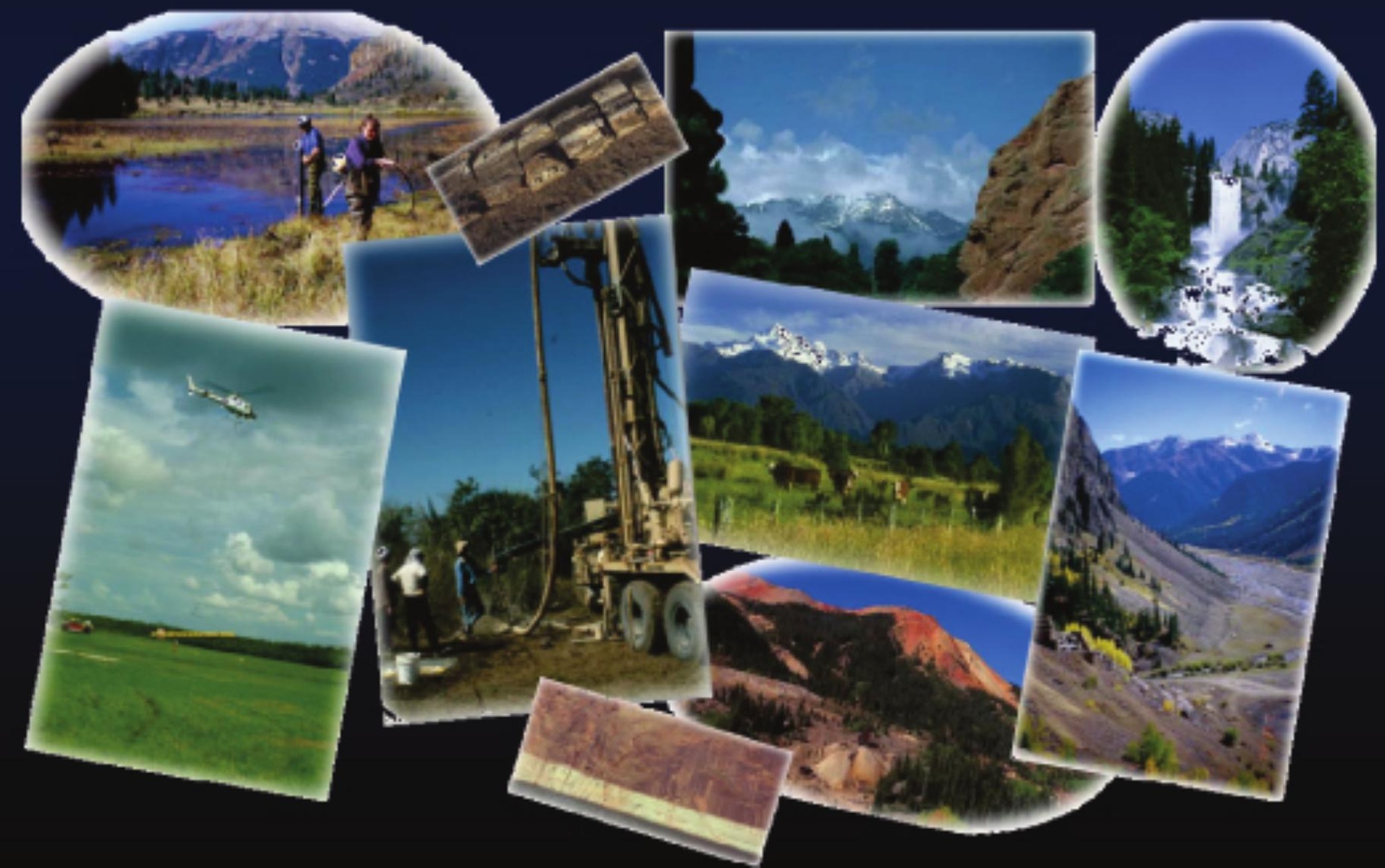


Analytical Results can be NO

\section{better than the sample submitted.}




\section{What? Why? When? How?}

-What medium to sample-you must define the target population (part or the whole)

- What are the reasons for sampling

- Question(s) to be answered by this sampling

- Desired degree of confidence in the answer(s)

-When to sample-temporal issues

You'll never know the true answer, but you can make a reasonable estimate of the truth!! 


\section{Mercury Remains a Major Environmental Problem}

- Industrial and Military Sites

- Fossil fuel combustion (power plants and transportation)

- Food chain enhancement (biota pathways to humans)

- $\mathrm{Hg}$ is still a growing problem in many areas as is demonstrated by the large increase of advisories for fish consumption 


\section{Sources of $\mathrm{Hg}$ in the Environment}

- Estimated anthropogenic input estimated at $>6 \times 10^{6} \mathrm{Kg} /$ year

- Fossil fuel burning and volcanic activity

- Industrial input (including waste incineration)

- Weathering of geological materials, especially $\mathrm{Hg}$ ore deposits and organic-rich sediments

- Agriculture (pesticides), mining activities, especially historic precious metal recovery and sulfide ore development

- Mining and precious metal recovery 


\section{Mercury General Geochemistry}

- Crustal abundance of 0.08 ppm

Soil (0.06 ppm), Limestone (0.04 ppm),

Shale (0.02-0.4 ppm), Water (0.07 ppb - but this

is an old estimate from the late 1970's and may

overestimate the real water abundance)

- Chalcophile associations (Sulfur-Loving)

(As, Sb, Se, Ag, Fe, Zn, Cu, Pb, Cd)

- High vapor pressure and liquid phase at ambient temperatures and pressures

- Commonly associated with organic matter and adsorbed onto clays, oxides, etc. 


\section{Soil Mercury Generalizations}

- Concentrates in the surface horizons

- Correlates well with organic carbon content

- Mobile in the subsurface as organic compounds

- Forms precipitates as sulfide, hydroxides, phosphates, or carbonates

- Methylated aerobically or anaerobically

- Adsorbed onto clays, hydroxides, oxides 


\section{Analytical Challenges}

- Widespread anthropogenic Hg contamination.

- High volatility of $\mathrm{Hg}$ and most of its compounds (losses in sample preparation are very possible).

- Wide range of values possible (low ng/L in aqueous samples) to 100 's of $\mathrm{mg} / \mathrm{Kg}$ in solids.

- Solid sample heterogeneity (density, phase associations).

- Blanks!!! Use double-distilled (sub-boiling point methods) acids and water, stored in Teflon ${ }^{\circledR}$. Methods are usually blank limited because of reagents.

- Clean all bottles with $10 \%$ nitric acid by soaking at least overnight. 


\section{Methods of Mercury Analyses}

A method should be able to detect $\mathrm{Hg}$ in the sub-part per billion range $(\mathrm{ng} / \mathrm{g})$ for solids and $\mathrm{pg} / \mathrm{L}$ for waters

ICP-AES, ICP-AFS, ICP-MS*, INAA

GF-AAS, F-AAS, CV-AAS*, CV-AFS*

Thermal decomposition - AAS (TD-AAS)*

*methods available to CICT, USGS (summarized in CICT methods manual USGS Open-File Report 02-0223) 


\section{Hg Method Requirements}

- Inorganic, organic, and adsorbed species of $\mathrm{Hg}$ are possibly present in the sample

- Rigorous digestion, but it must limit $\mathrm{Hg}$ volatilization problems

- Minimize Hg contamination from other samples, reagents, labware, and laboratory

- Large dynamic range 


\section{Standard Reference Materials}

- Define and monitor accuracy and precision quantitate the quality of the results

- Establish effective working range

- Must be analyzed routinely

- Extensive list of SRMs available ranging from low ppb to over 100 ppm Hg

- Should try to match the sample matrix, if possible 


\section{SRM's for Fish Tissue, Hg (ppm)}

- NRC Can DOLT 2 (dog fish liver)

$2.14 \pm 0.28$

- NRC Can DORM 2 (dog fish muscle)

$4.64 \pm 0.26$

- NRC Can TORT-1 (lobster)

$0.33 \pm 0.06$

- $\mathrm{NIST} 1641 \mathrm{~d}\left(\mathrm{Hg}\right.$ in $\left.2 \% \mathrm{HNO}_{3}\right)$

$1.590 \pm 0.018$

$0.037 \pm 0.001$

$0.0399 \pm 0.0007$

$0.034 \pm 0.004$

0.003

- NIST 1577b (bovine liver) 


\section{Selected SRM's for Geological Materials, Hg (ppm)}

- USGS SDO-1 (marine sediment)

0.190

- NRC Can BCSS-1 (marine sediment)

- NRC Can MESS-1 (marine sediment)

0.129

- NIST 1645 (river sediment)

0.171

- NIST 1646 (sediment)

- NIST 8408 (river sediment)

1.1

1.44

- NIST 2781 (domestic sludge)

$107 \pm 2$

$3.64 \pm 0.25$

- NIST 2711 (soil)

$6.25 \pm 0.19$

- NIST 2710 (soil)

$32.6 \pm 1.8$

- NIST 2709 (soil)

$1.40 \pm 0.08$ 


\section{Leeman Hydra ${ }^{\circledR}$ AFS Instrumentation}
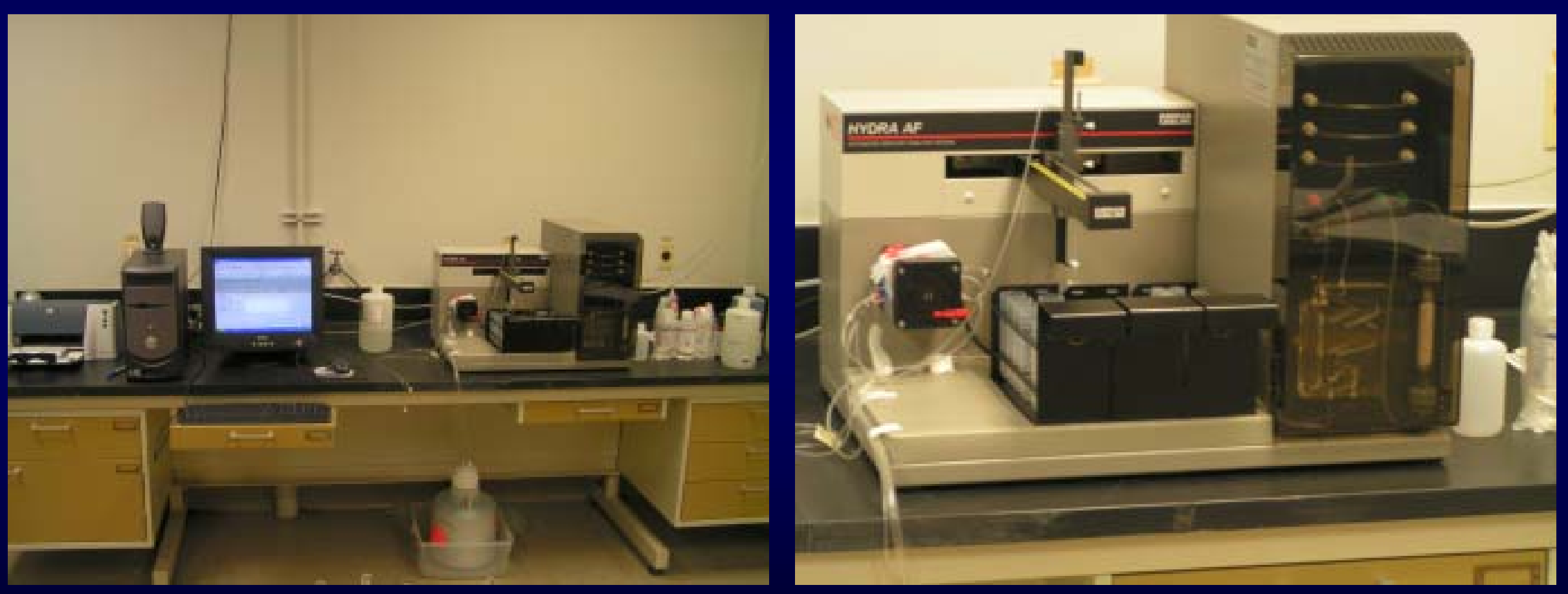


\section{Continuous-Flow-Cold-Vapor-Atomic}

Absorption Spectrometry

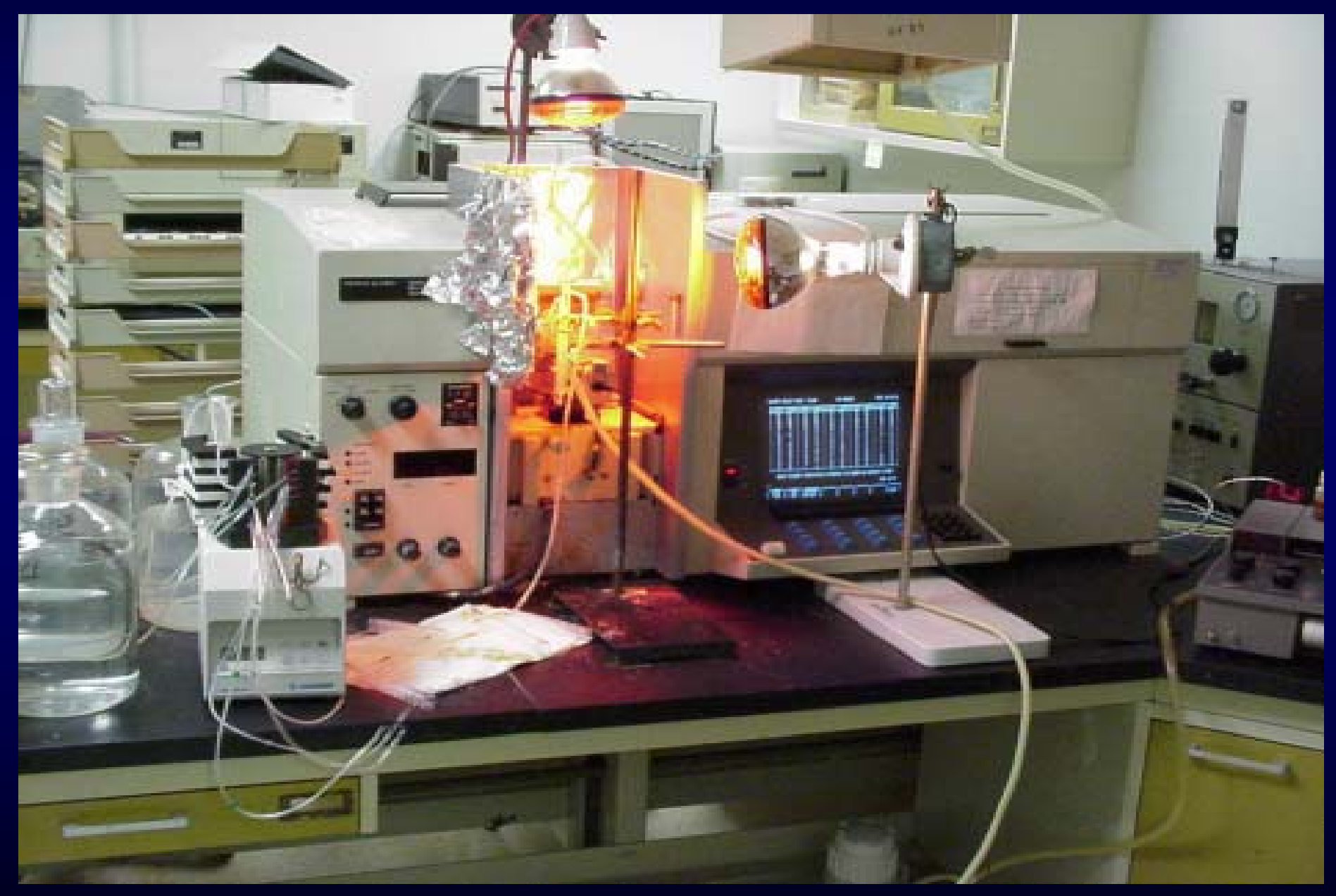




\section{Flow-through Pyrex ${ }^{\circledR}$ glass cell for CF-CV-AAS}

Analytical Stream

From Phase Separator Quartz End
Window Quartz End
Window 1 $155 \mathrm{~mm}$

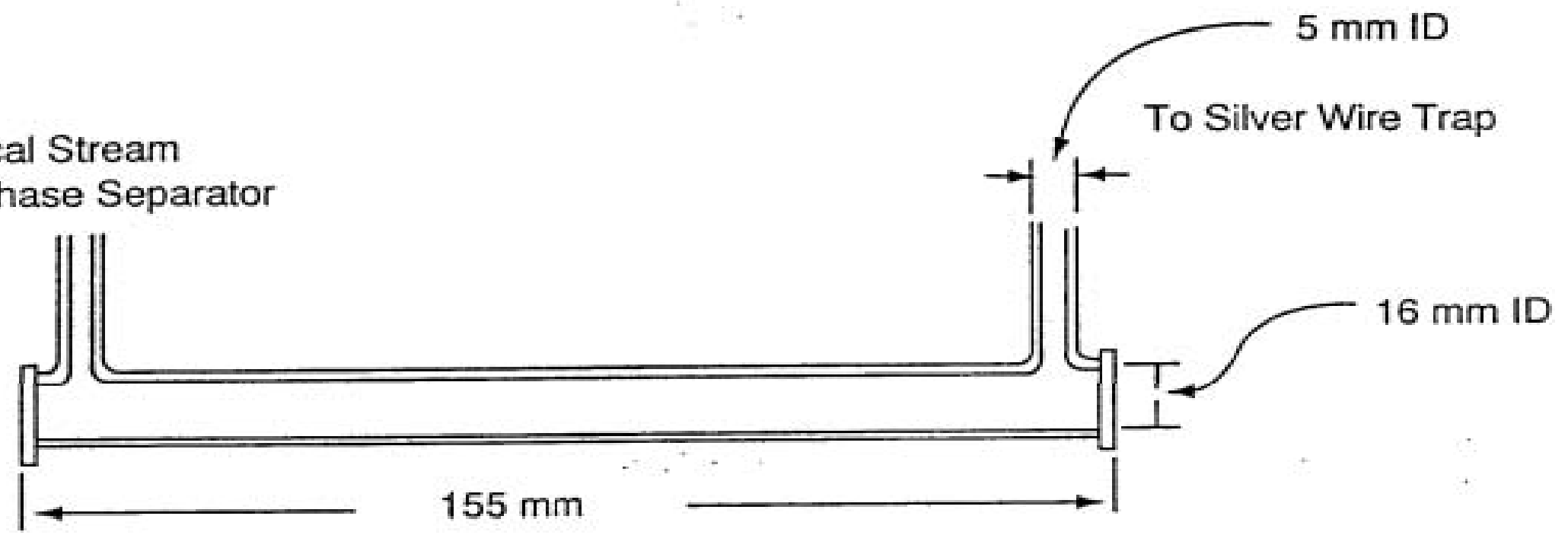

To Silver Wire Trap 


\section{Pyrex ${ }^{\circledR}$ glass Phase Separator for}

CF-CV-AAS

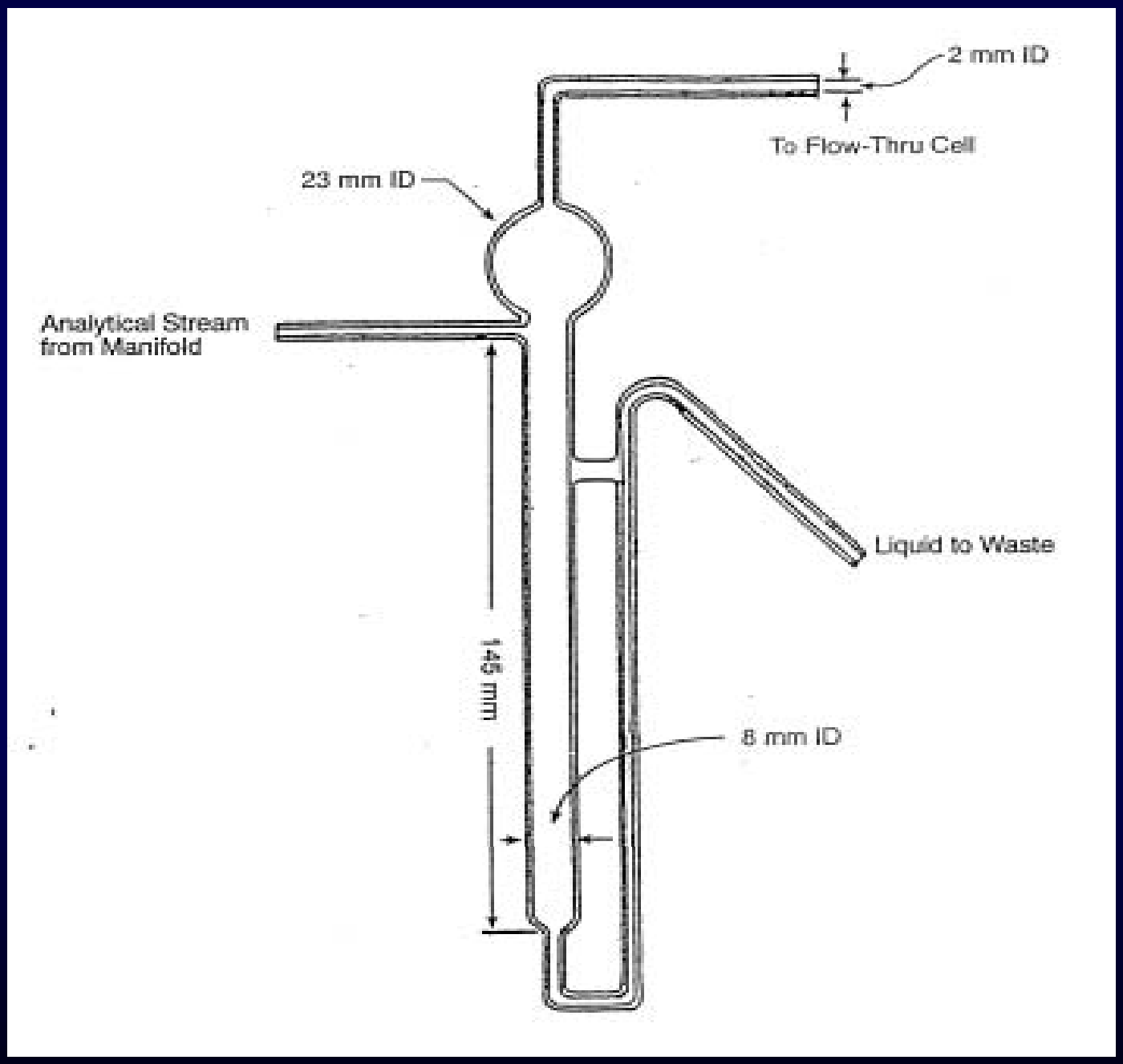




\section{Schematic for the CV-AFS Generator}

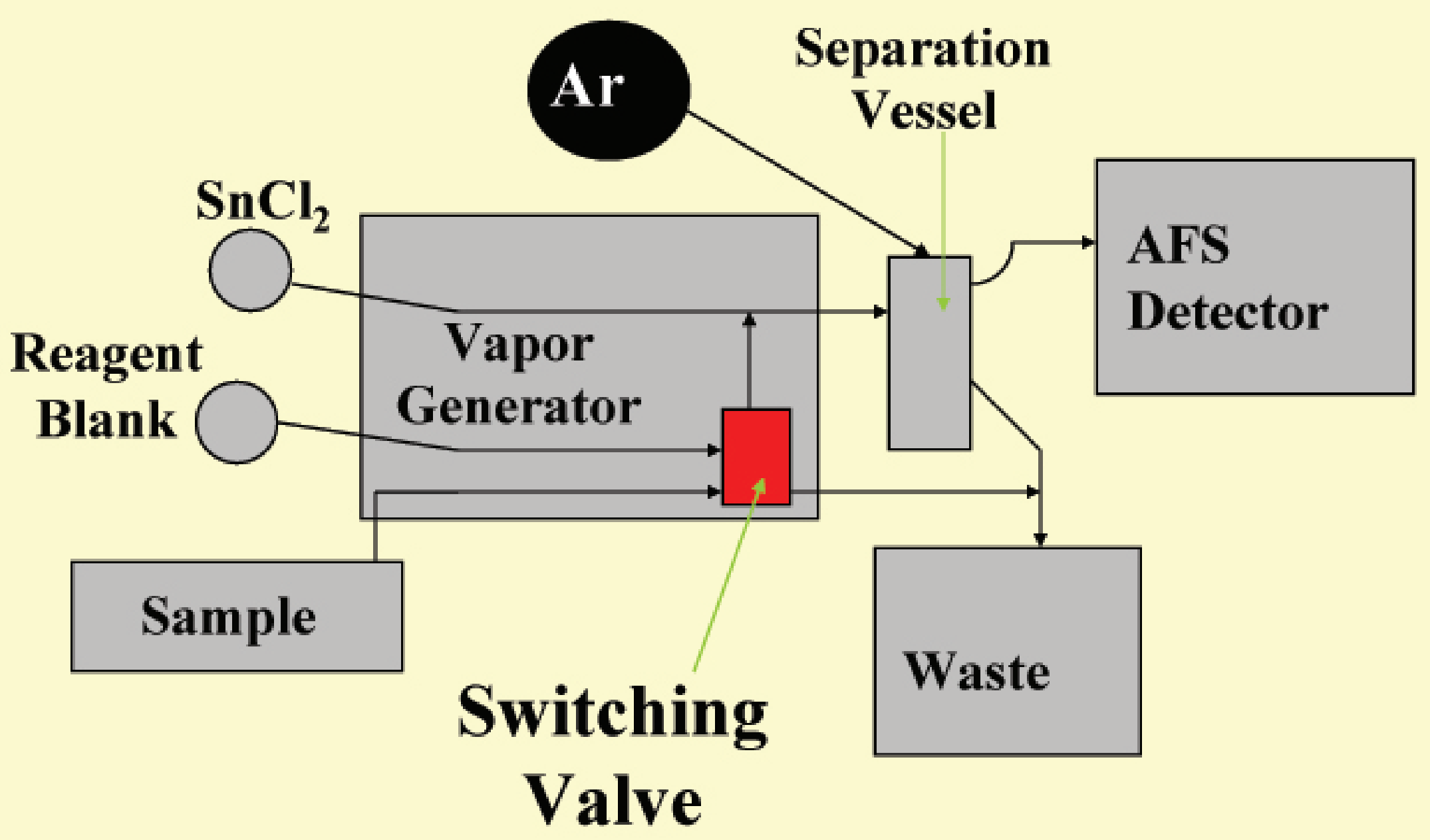




\section{Thermal Decomposition - AAS}
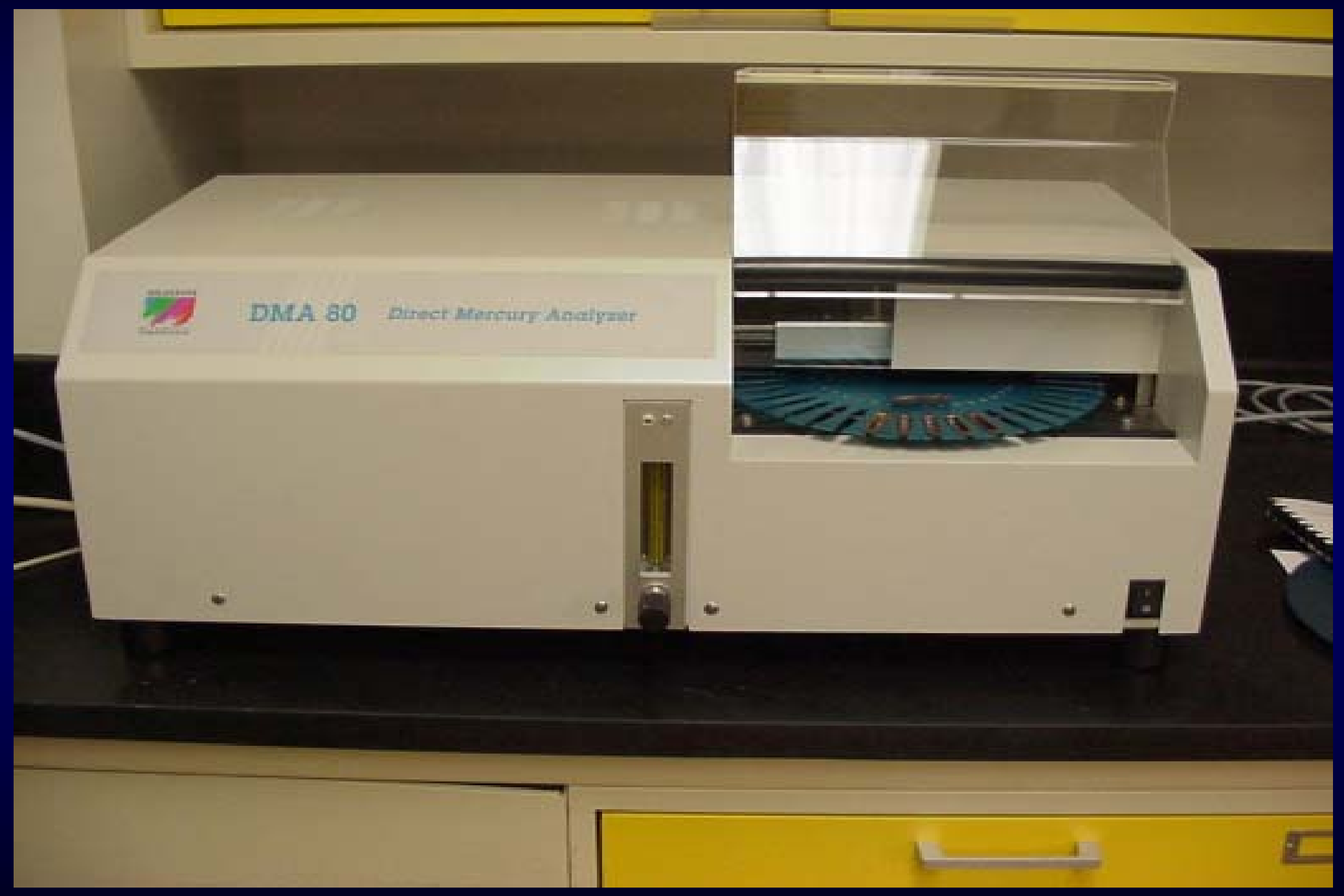


\section{Thermal Decomposition - AAS Methodology Outline}

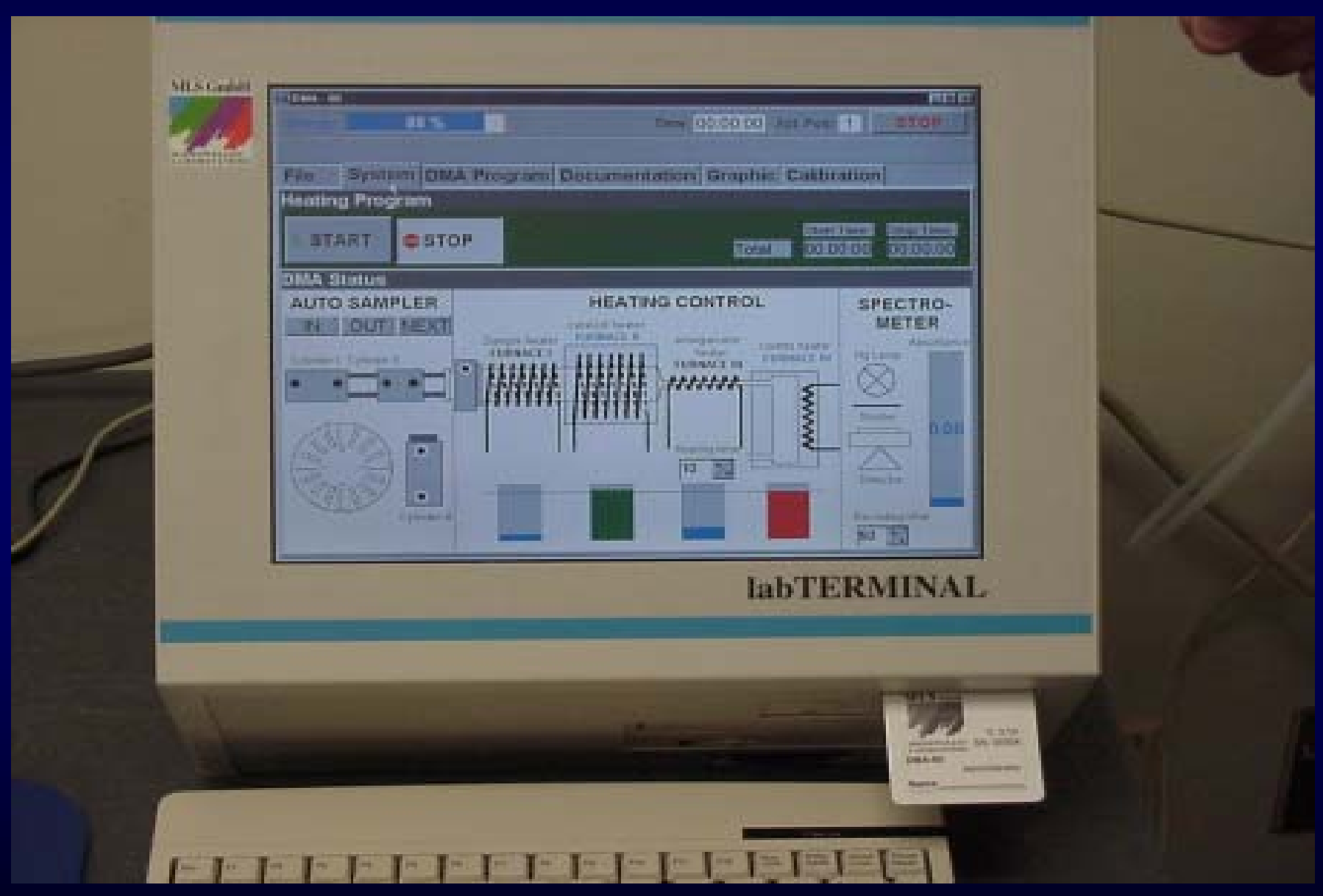




\section{Schematic of Hg Thermal Decomposition Method}

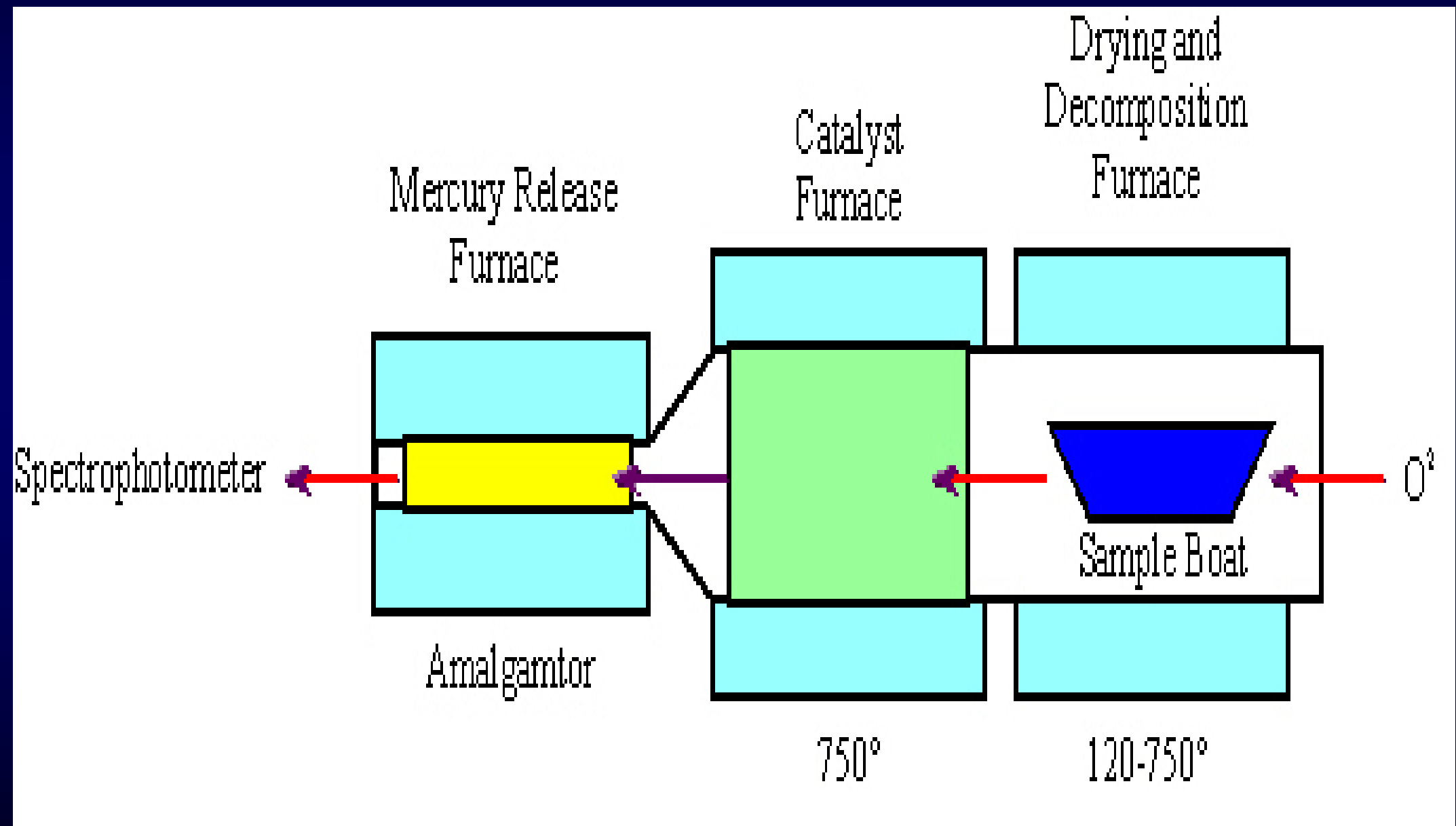




\section{Methods of Determining Mercury by}

ICP-MS

- Can be coupled with vapor generation and amalgamation for increased sensitivity

- Direct comparison with aqueous or solid (laser ablation) standards

- Standard addition of standard solutions

- Simultaneous determination of multiple isotopes with addition of a known amount of an enriched-isotope standard (Isotope Dilution)

- Laser ablation of solids - applicable to tree cores, rock core profiles, glasses, pressed pellets of powered materials, fused samples 


\section{Role of ICP-MS in the Analysis of}

Mercury in Natural Waters

- Accurately determine mercury concentrations in secondary reference standards used to validate mercury concentrations in unknown water samples.

- Determine mercury concentrations in critically important water samples with difficult sample matrices. 


\section{ICP-MS vs. CV-AFS for Routine Monitoring of}

\section{Mercury in Natural Waters}

- ICP-MS

- PRO

- extremely accurate

- no matrix effects

$-\mathrm{CON}$

- long analysis time

- costly

- instrumentation difficult to setup and maintain

- major memory effects
- CV-AFS

- PRO

- superior detection limit

- easy to maintain

- matrices are controlled

- memory effect corrected

- fast analysis time

- inexpensive to operate

- CON

- standardization required

- needs check by SRWS 


\section{CV-AFS AND CV-AAS METHODOLOGY}

\section{Four Basic Steps}

- Sample decomposition $\{$ all $\mathrm{Hg}$ to $\mathrm{Hg}(\mathrm{II})\}$

- Quantitative Reduction of $\mathrm{Hg}(\mathrm{II})$ to $\mathrm{Hg}^{\mathrm{O}}$

- Phase separation

- Hg measurement/quantification 


\section{Digestions}

- Must be vigorous and highly oxidative

- Use strong mineral acids (HF not required), auxiliary oxidants, high temperatures and(or) pressure

- Direct and(or) indirect, microwave heating

- Open or closed vessels with "hotplate methods"

- For most biological samples, freeze drying is essential! (It preconcentrates elemental compositions by up to a factor of 10 by eliminating water while digestion reagents are not diluted.) 


\section{Freeze Drying the Biological Tissues}
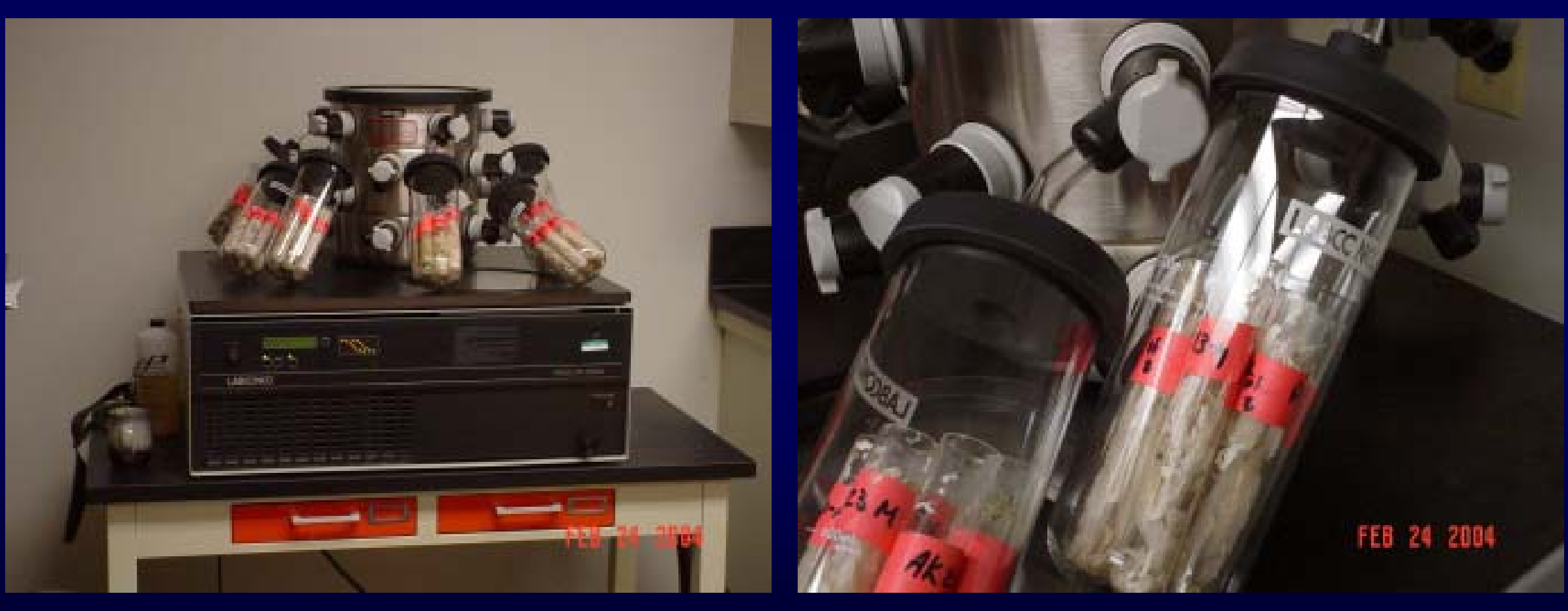
Microwave Digestion Oven and Digestion Vessel
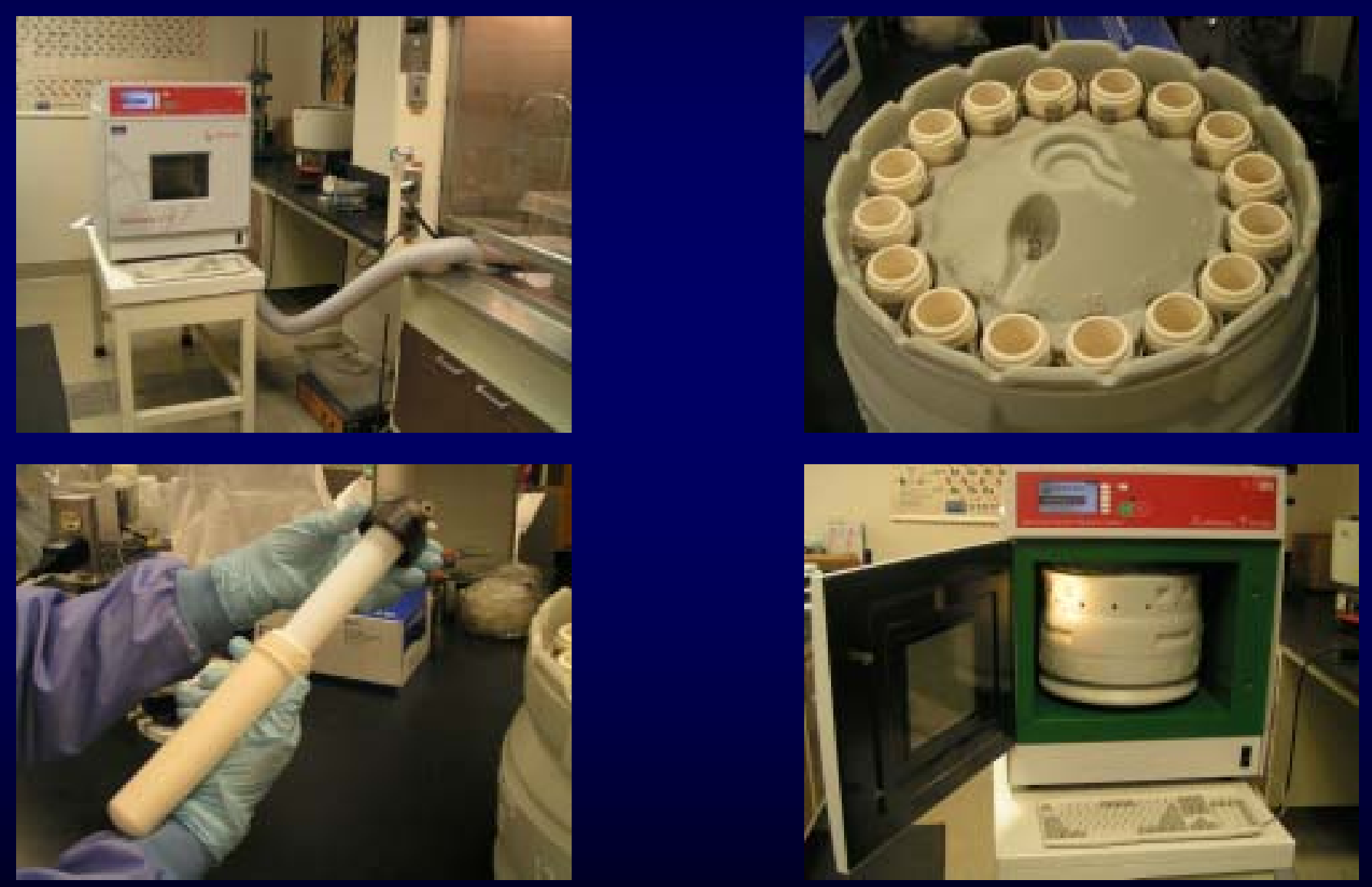


\section{Hotplate Digestion for Biological Matrices}
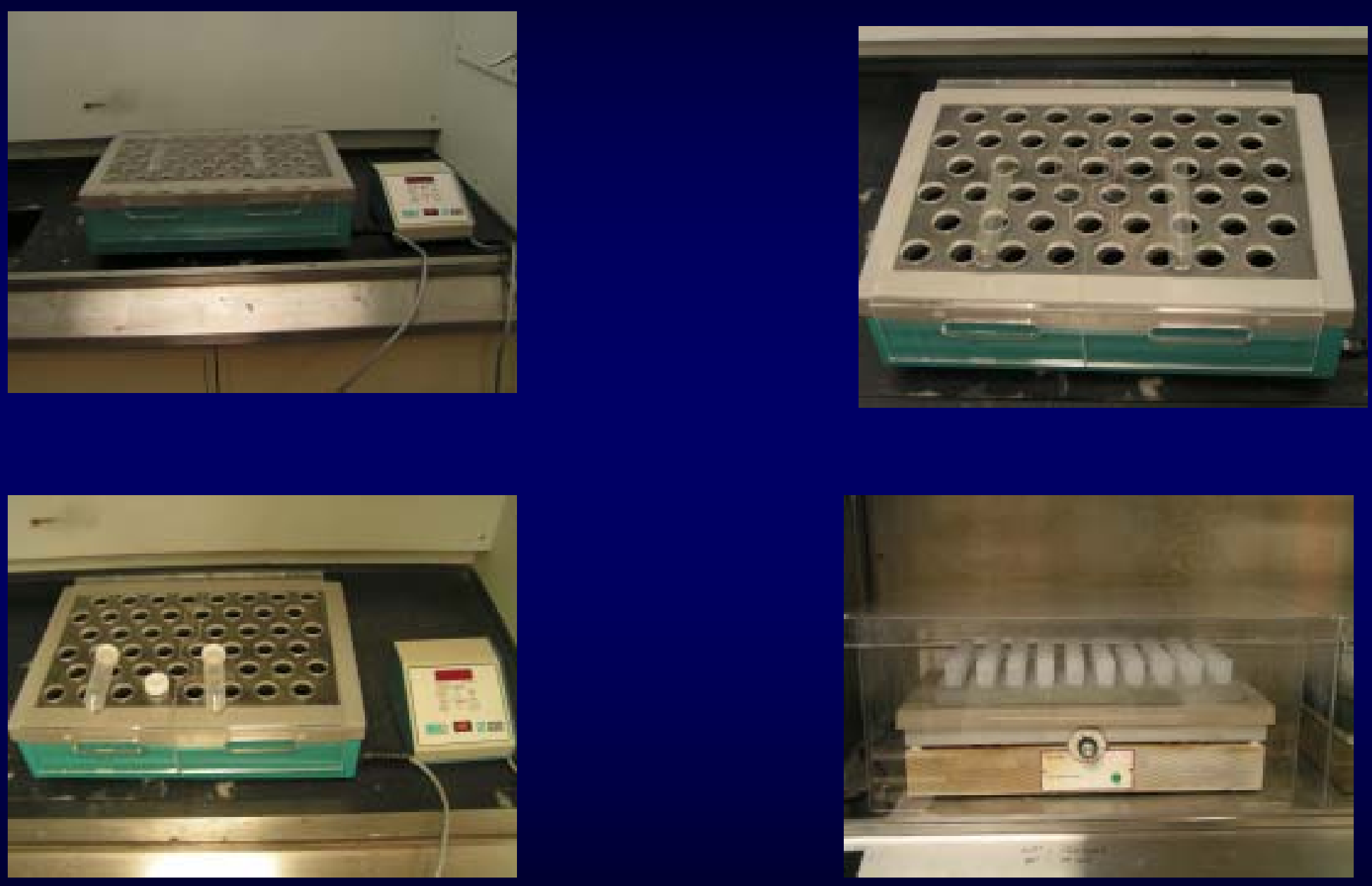


\section{Microwave Digestion for Fish Tissues}

\section{and Sludges}

Weigh $0.5 \mathrm{~g}$ (sludge) or $0.25 \mathrm{~g}$ (fish) into Teflon ${ }^{\circledR}$ vessel. Add $2 \mathrm{~mL}$ water and $5.0 \mathrm{~mL}$ nitric acid.

- Step 1: Ramp to $200 \_C$ over a 30 min program. Cool to room temperature ( $45 \mathrm{~min})$.

- Step 2: Add $1.5 \mathrm{~mL}$ hydrogen peroxide.

- Step 3: Ramp to $200^{\circ} \mathrm{C}$ over a 20 min program and cool.

- Step 4: Pipette an aliquot of digest ( $<2 \mathrm{~mL})$ into a $16 \mathrm{~mm}$ test tube, add $1.5 \mathrm{~mL}$ of the dichromate reagent, dilute with water to volume and analyze by CV-AAS. 


\section{Digestion Method for Coals and Biological Samples}

- Weigh $0.15 \mathrm{~g}$ coal or dry tissue ( 0.75 to $1.5 \mathrm{~g}$ wet tissue) into a $16^{*} 150 \mathrm{~mm}$ test tube.

- Add $\sim 0.1 \mathrm{~g}$ vanadium pentoxide, $3.5 \mathrm{~mL}$ nitric acid, and $1.5 \mathrm{~mL}$ sulfuric acid. Mix well.

- Cover with watch glass, ramp slowly (2 hours) to $150 \circ \mathrm{C}$ in an Al heating block. Maintain temperature overnight.

- Remove from heating block and cool. Dilute to $15 \mathrm{~mL}$ with water. Mix well and centrifuge. Analyze with CV-AAS or ICP-MS. Matrix match the standards. 


\section{Dichromate Digestion Procedure (Manual or Robotic)}

- Weigh $0.1-0.5 \mathrm{~g}-100$ mesh sample into a $30 \mathrm{~mL}$ Teflon® bottle.

- Add $2.0 \mathrm{~mL}$ nitric acid and $0.5 \mathrm{~mL}$ sodium dichromate solution.

- Cap, heat at $110^{\circ} \mathrm{C}$ for 3 hours in an Al block.

- Cool, transfer into flint glass test tube and bring to volume with distilled water. Mix. Let settle. 


\section{Reduction}

- Must be quantitative

- Stannous Chloride (sodium borohydride)

- Source of most chemical interferences (more severe when using sodium borohydride)

- $\mathrm{Hg}^{+2}{ }_{\mathrm{aq}}+\mathrm{Sn}+2_{\mathrm{aq}} \rightarrow \mathrm{Sn}+4{ }_{\mathrm{aq}}+\mathrm{Hg}^{0}$ (gas) 


\section{Transportation and Separation}

- Minimize surfaces contacted

- Surfaces should be glass or Teflon ${ }^{\circledR}$ and be warmed (prevents $\mathrm{Hg}^{\mathrm{O}}$ loss by adsorption to the labware)

- Distribution coefficient between phases relatively independent of most variables 


\section{Reagents for CV-AFS}

- Sodium Dichromate : $25 \% \mathrm{~W} / \mathrm{V}$, in concentrated Nitric Acid

- Stannous Chloride: $2 \% \mathrm{~W} / \mathrm{V}$, in $1.2 \mathrm{M} \mathrm{HCl}$

- Nitric Wash: 0.16 M Nitric Acid (1\% V/V) 


\section{Standards (traceable to NIST 1641c)}

CV-AFS

$0,0.0294,0.073,0.147,0.294$, and $0.730 \mu \mathrm{g} / \mathrm{L} \mathrm{Hg}$ in $0.5 \%(\mathrm{~W} / \mathrm{V})$ Sodium Dichromate in 3.2 M Nitric Acid

CV-AAS

$0,1,5$, and $10 \mu \mathrm{g} / \mathrm{L} \mathrm{Hg}$ in $0.5 \%$ (W/V) Sodium Dichromate in 3.2 M Nitric Acid

(All dichromate will be eliminated from this method in the near future.) 
Elements showing no interference on a $10 \mu \mathrm{g} / \mathrm{L}$ Hg standard determined by CV-AAS and a $0.1 \mu \mathrm{g} / \mathrm{L} \mathrm{Hg}$ solution determined by CV-AFS

- 100 ppm

- 50 ppm

- 10 ppm

- 50 ppm

- 3 ppm

- 1 ppm
$\mathrm{Zn} \mathrm{Pb} \mathrm{Mn}$

$\mathrm{Cu} \mathrm{Fe}$

Co V U Mo Ni

Cd Bi

As

Sb 


\section{Interfering Elements in CV-AAS and CV-AFS in the reduction step}

Se Au Te Pt Ag

Water vapor and chlorine gas also interfere in the detection step. 


\section{Applications of Different Mercury Methods at the USGS}

- Baseline/Background geochemical studies of soil profiles, vegetation, and rocks (CV-AAS or TD-AAS) and water and soil extracts (CV-AFS) for mining activities in Alaska, Nevada, and Colorado

- Reference material characterization (all methods)

- Environmental studies including the analysis of fish tissues (Yellowstone National Park) (CV-AAS or AFS)

- Sewage sludge monitoring program for agricultural applications, including the wheat (both the grain and the entire plant), soils, water, sludges, and parent rocks (all methods) 


\section{Applications (Continued)}

- Power plant impact (vegetation, water, soil) (CVAAS, CV-AFS, and/or TD-AAS)

- Analysis of coal and coal by-products (CV-AAS or TD-AAS)

- Rock and soil extracts (CV-AAS or CV-AFS)

- Ground and spring waters (ICP-MS or CV-AFS)

- Shell, bone fragments, and hair samples (CVAFS, TD-AAS) 
Results of Elemental and Stable Isotopic Measurements, and Dietary Composition of Arctic Grayling (Thymallus arcticus) Collected in 2000 and 2001 from the Fortymile River Watershed, Alaska

by J.G. Crock, R.R. Seal II, L.P. Gough, and

P. Weber-Scannell

This report is preliminary and has not been reviewed for conformity with U.S. Geological Survey editorial standards or with the North American Stratigraphic Code. Any use of trade, firm, or product names is for descriptive purposes only and does not imply endorsement by the U.S. Government.

Open-File Report 2003-03-057

U.S. DEPARTMENT OF THE INTERIOR U.S. GEOLOGICAL SURVEY 


\section{Arctic Grayling}

Important salmonid subsistence and sport fish

Circum-boreal in distribution

Non-anadromous (doesn't possess a sea-run phase)

Migrate up to $100 \mathrm{Km}$ between summer feeding areas and overwintering ice-free deep pools

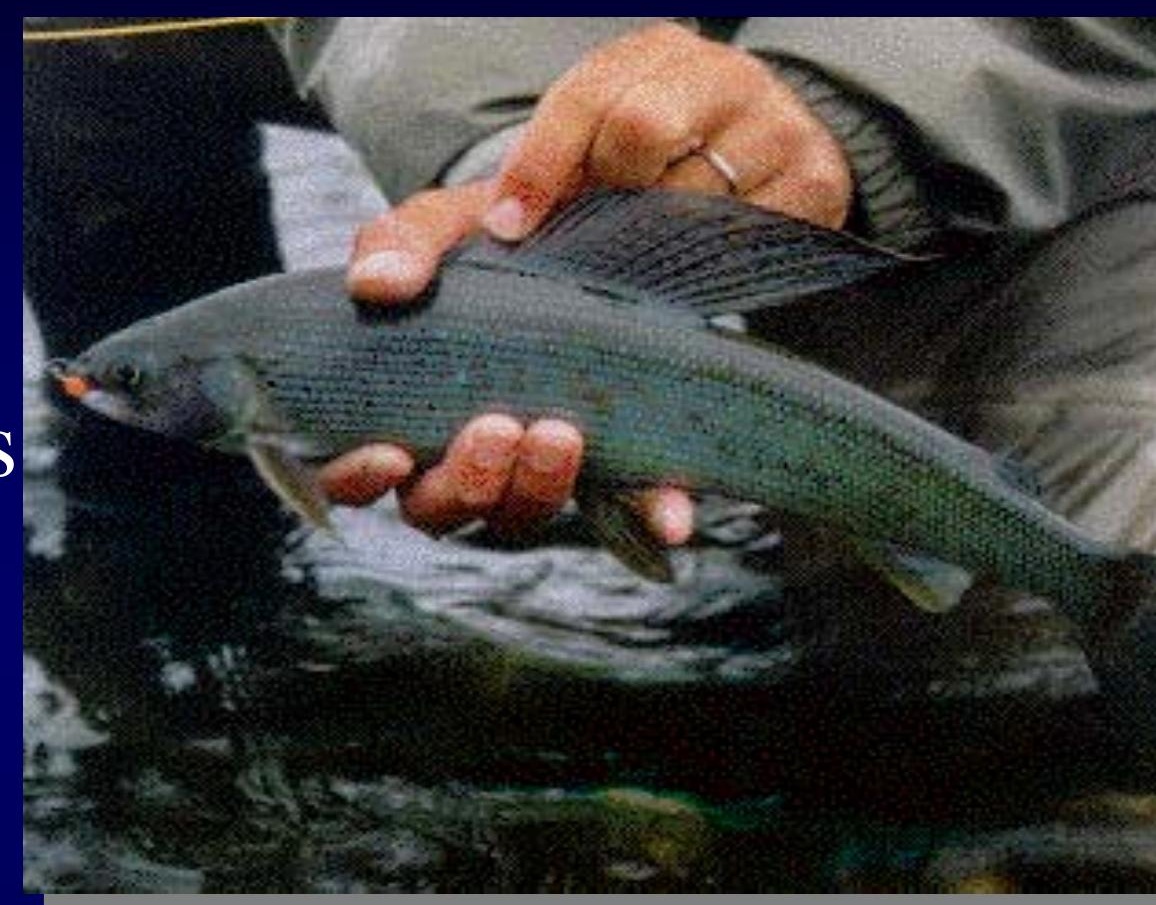

Display remarkable inter-year fidelity to summer feeding sites (productive feeding site adaptation)

Some data on over-wintering fidelity as well

Voracious feeders! 


\section{Field Methods:}

- Collected by rod and lure - September 2000: period of maximum weight gain and prior to winter migration

- Similar weight (age) and length

- Three each (mix of male/female) from 10 sites on $80-\mathrm{km}$ stretch of main stem plus four from tributary

$13-\mathrm{km}$ north $(\mathrm{n}=34)$

- Dissected in the field (muscle, liver, stomach contents); frozen; shipped to labs

- Standard sampling and laboratory QA/QC 


\section{Fortymile Grayling Study}

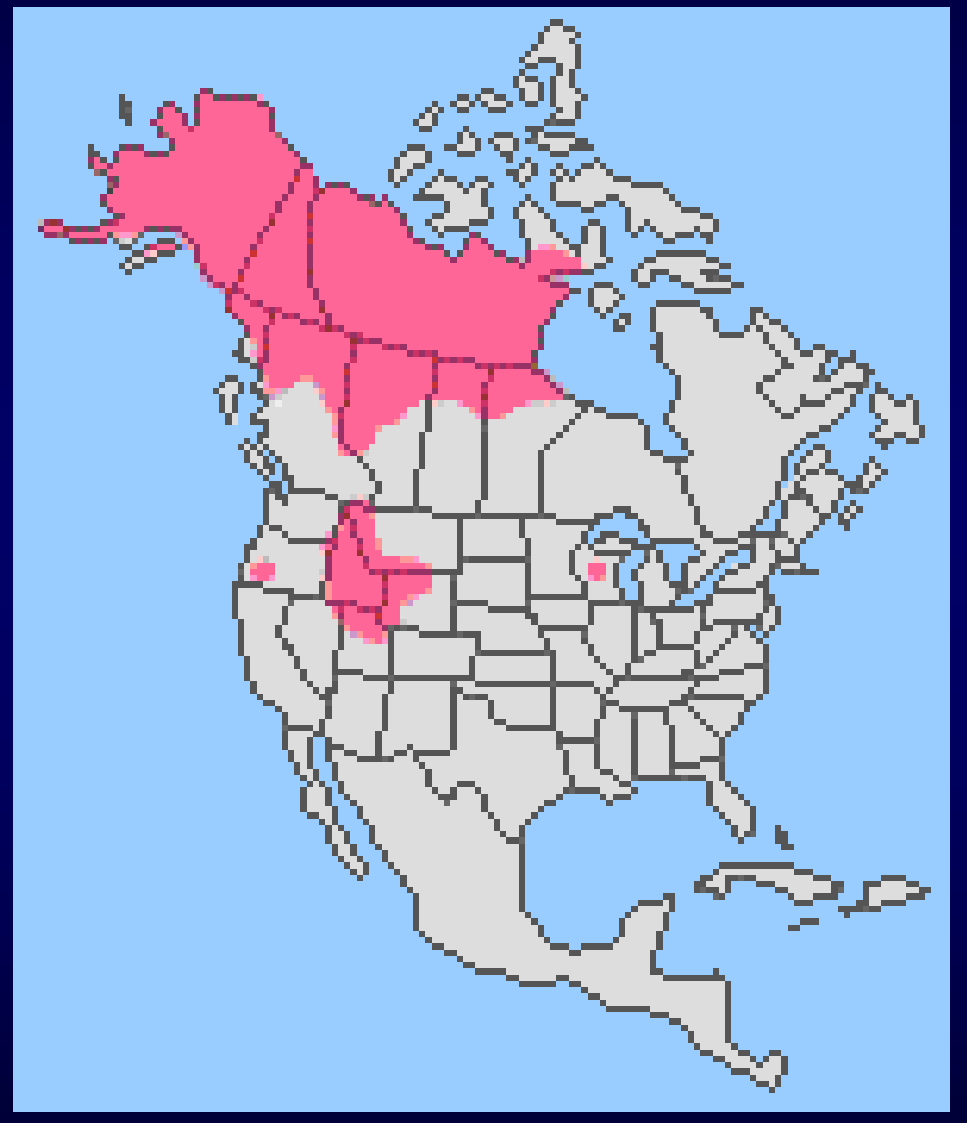

Grayling Range

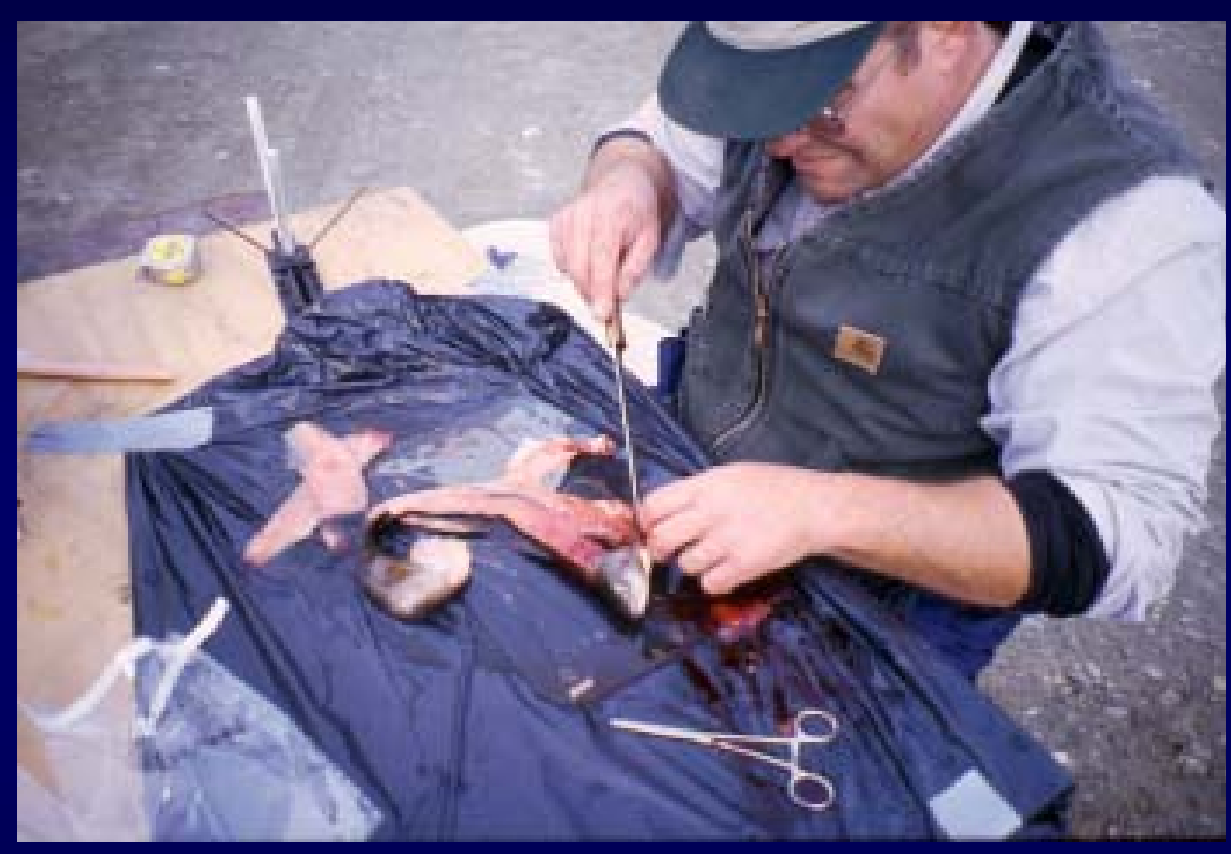

Field Dissection for fillet, stomach, and liver 


\section{Digestion and Sample Preparation}

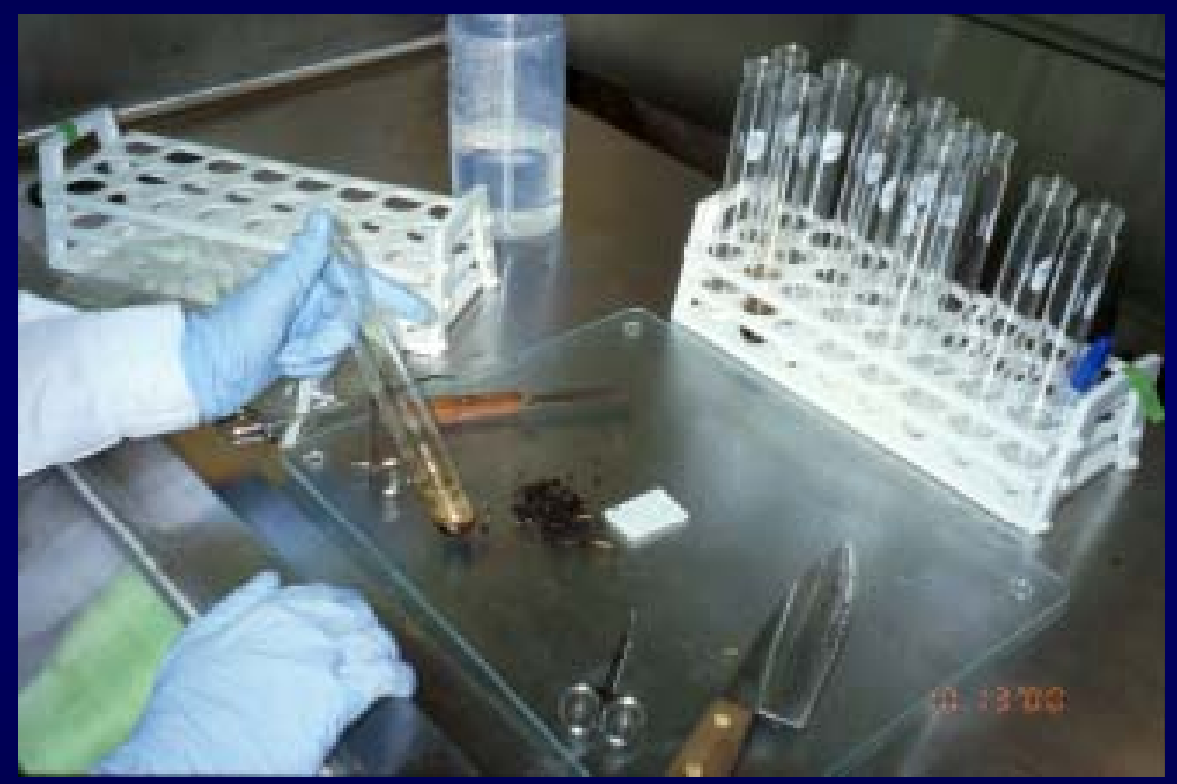

Stomach Contents with $\mathrm{HNO}_{3}$

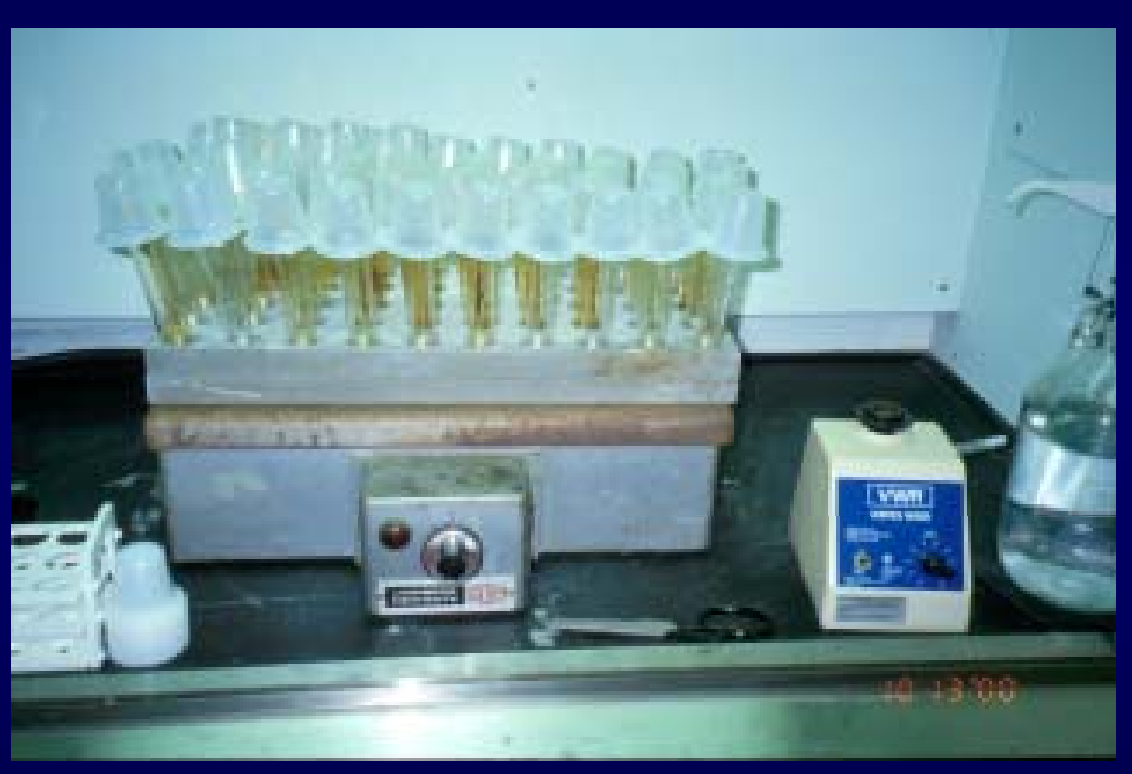

Hotplate Digestion 
Simple regression of fish weight vs. total $\mathrm{Hg}$ in muscle tissue (wet-weight basis)

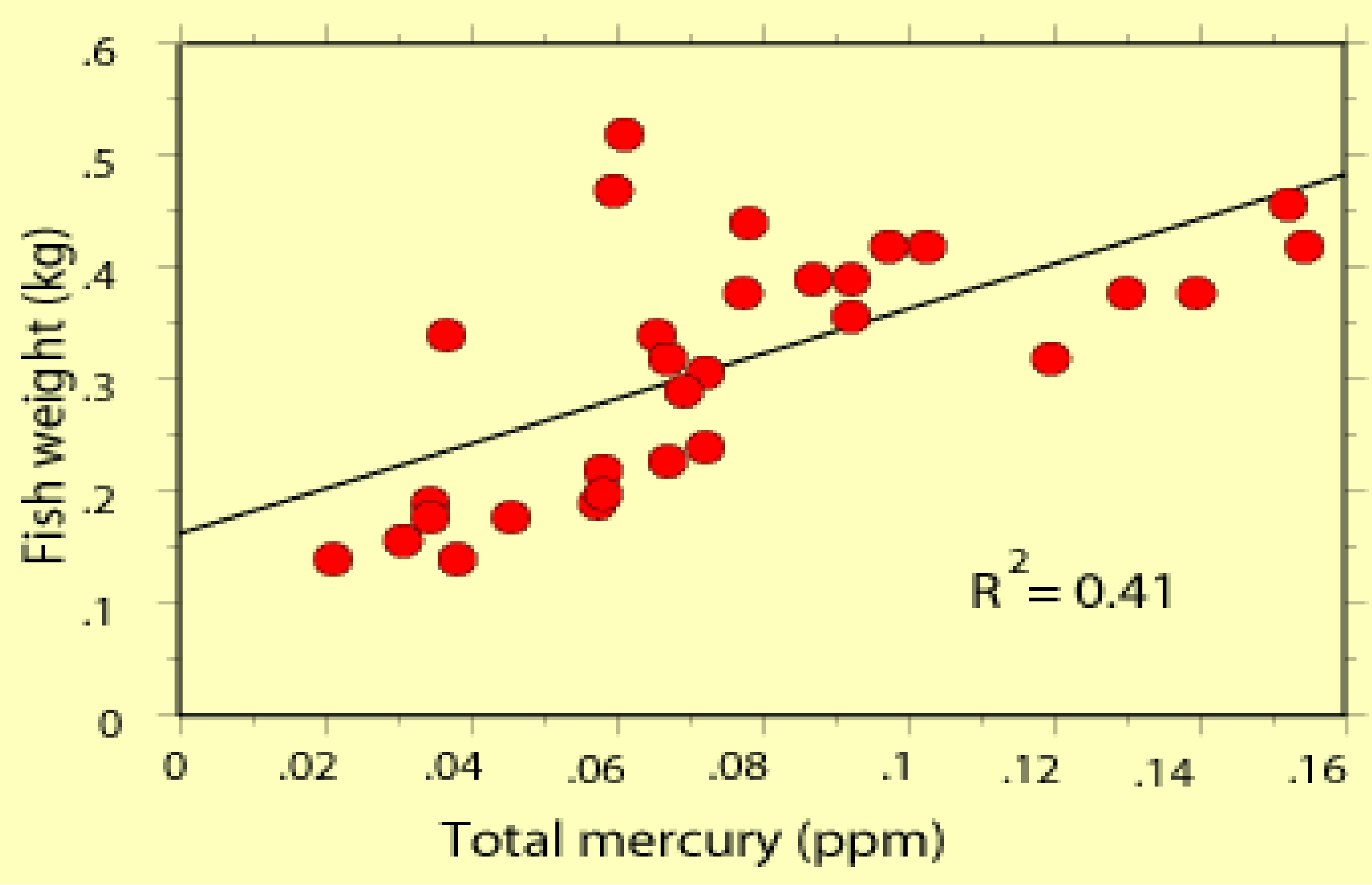




\section{Summary}

Total $\mathrm{Hg}$ levels in fish muscle ranged from $0.021-0.15$ ppm (wet-weight basis) with a GM of $0.069 \mathrm{ppm}$; for liver tissue $0.031-0.10 \mathrm{ppm}$ with a GM of 0.062-nearly an order of magnitude below the FDA permissible values for $\mathrm{MeHg}$.

Biogeochemical baseline values and/or ranges were developed for 38 elements in grayling muscle, liver, and stomach contents from a watershed with a mix of lithologic units.

Hg shows a physiological positive correlation with fish weight (age); most other trace elements do not show a physiological association. 


\section{$\mathrm{Hg}$ in Tanner Crabs, Glacier Bay, Alaska}
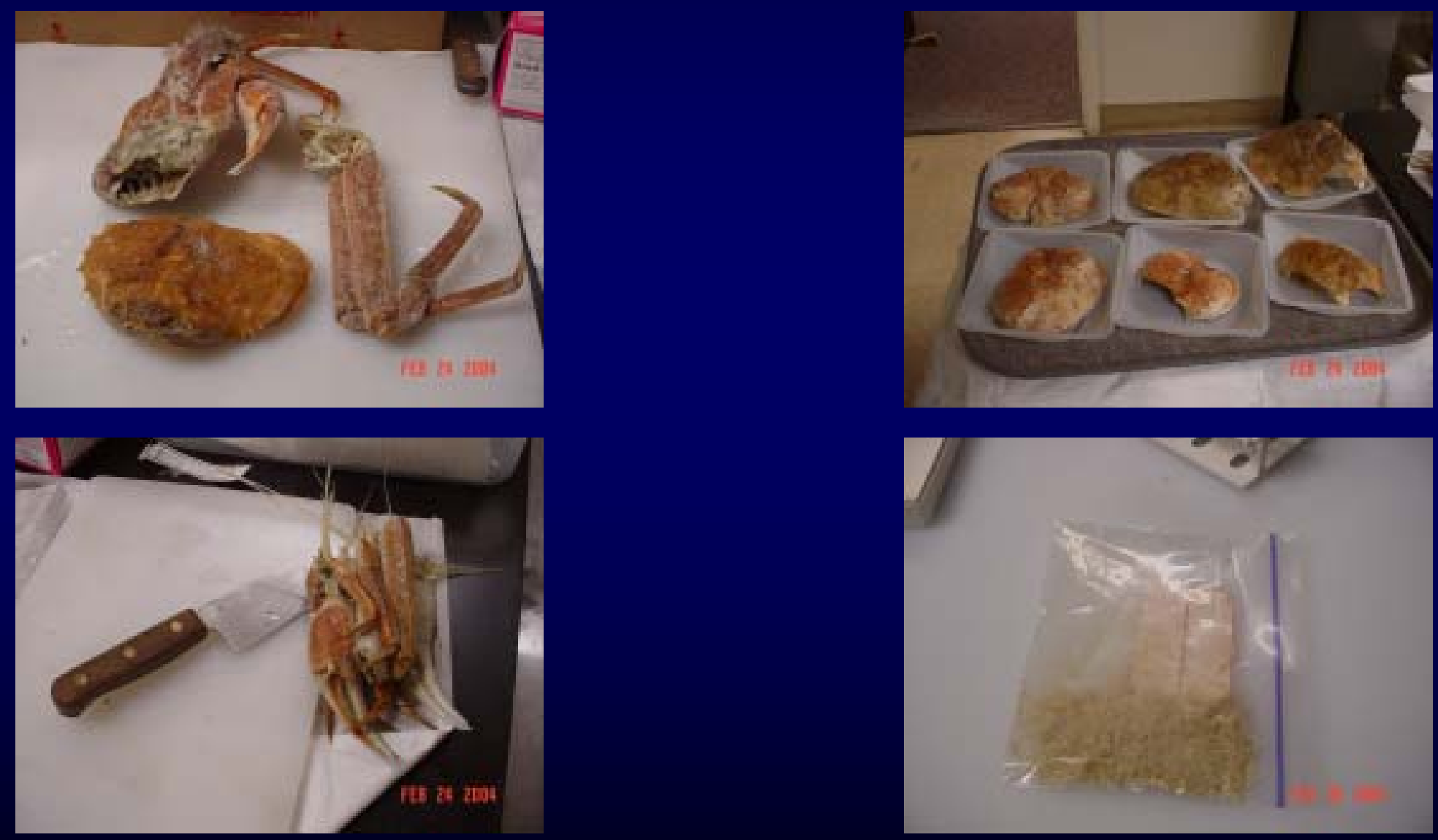


\section{Preliminary Results for $\mathrm{Hg}$ (ppm) in Tanner Crabs, Glacier Bay}

Sample Matrix

Carapace (shell)

Leg Sheaves

Body Meat

Leg Meat
Range

$0.03-0.042$

$0.03-0.27$

$0.09-0.68$

$0.13-0.62$
Mean

0.013

0.012

0.26

0.31 


\section{Questions?}

- Would you really eat this fish?

- Answer - YES!! Grilled with garlic and lime. 